\title{
The Impact Of Online Learning Toward Students' Academic Performance On Business Correspondence Course
}

\author{
Berlinda Mandasari \\ Universitas Teknokrat Indonesia \\ berlinda@teknokrat.ac.id
}

Article History:

Received: June $12^{\text {th, }} 2020$

Revised: August 13th, 2020

Accepted: September 30th, 2020

\begin{abstract}
Covid-19 pandemic becomes global issue that gives global impact in all sectors especially in educational one. The Minister of Education and Culture of Indonesia make a policy in which all education sector is shifted from face-to-face learning into online learning. This policy is well-responded by one of private universities in Lampung. The researcher conducted a research to response this policy. The objective of this study is identify the impact of online learning toward students' academic performance on Business Correspondence course. Participants of this study are 40 students (14 male and 26 female) who enrolled Business Correspondence course at English Education study program of Universitas Teknokrat Indonesia. The design of this research is descriptive qualitative. Data were collected through questionnaire that consists of 22 statements and openended interview. The result showed that online learning has positive impact on students' academic performance in term of learning motivation, learning achievement and learning engagement. Participants also showed that conducting online learning is relevant during pandemic. Furthermore, flexibility, accessibility, learning autonomy, and boosting students' achievement become the strengths of conducting online learning. However, financial issue and bad internet access become problems that hamper online learning.
\end{abstract}

Key words: Academic Performance, Business Correspondence, Online learning, Pandemic.

\section{INTRODUCTION}

The 2019 Corona virus (Covid-19) pandemic has a global impact on all sectors in Indonesia, including the education sector. All learning activities in schools and higher education are transferred to online learning by carrying out learning activities at home. This is based on the circular of the Minister of Education and Culture of the Republic of Indonesia number 4 of 2020 concerning the implementation of educational policies in the emergency period of the spread of Corona virus Disease (Covid-19)(Wajdi, Kuswandi, et al., 2020; Wajdi, 
Ubaidillah, et al., 2020). In responding to this policy, all leaders of education units and tertiary institutions have various ways of implementing learning activities in each educational unit.

Universitas Teknokrat Indonesia (UTI), as one of the private universities in Lampung has a quick response to the circular of the Minister of Education and Culture. The college where the author is affiliated issues policies that regulate lecturers and students in the implementation of learning. Based on the decree of Rector of Universitas Teknokrat Indonesia number 002/UTI/B.18/III/2020 concerning the prevention of the spread of Corona virus Disease (Covid-19) in Universitas Teknokrat Indonesia, the college provides a policy to replace face-toface lectures into online lectures. In this case, UTI uses the SPADA Platform as the main medium in implementing online learning.

In the implementation of online learning, there are many challenges faced by lecturers and students. The challenges faced by lecturers are that lecturers must prepare teaching materials, such as slides/teaching materials, learning videos, discussion forums, and post-tests for students. Based on the results of interviews with several lecturers, it was found that lecturers had to prepare more material to upload to their SPADA accounts when compared to face-to-face learning. In addition, lecturers also need to check student assignments/post-tests, both individually and in groups. Even though the essence of online learning is learning that can be carried out anytime and anywhere, this actually takes time for lecturers to prepare and check student assignments.

The challenges faced by students are related to student interactions with fellow students or with lecturers. Based on the results of the interview, it was obtained information that lectures in the network have limitations in terms of interaction. In face-to-face lectures, students can interact directly with lecturers or colleagues. This interaction can take the form of a discussion, question and answer or presentation. This kind of interaction can also take place online. However, the implementation is limited to indirect interaction. This presents a challenge for students on how to adapt to a learning model that limits direct/face-to-face interaction. Besides, network connection also presents its own challenges. Many students who live in their hometowns have limited access to the internet. In fact, they have to go to a certain area to be able to access the internet faster. This condition gets worse when the amount of internet quota decreases. This resulted in many students having difficulty adapting to the online learning model. Even so, there are several solutions offered to answer these challenges. First, lecturers provide flexibility for students to be able to access SPADA anytime and anywhere. Second, students are allowed to contact lecturers personally to submit complaints during online learning. This is done to maintain the quality of learning so that the learning objectives set can be achieved. 
Several studies on online learning have been conducted. Research conducted by Khusniyah, N.L., \& Hakim, Lukman. (2019) stated that online learning using a web blog has a positive influence on the learning process to read English so that it has an impact on increasing student learning scores. On the other hand, according to Mandasari, B. \& Aminatun, D (2019), students have positive attitude toward video blog in improving students' speaking ability. It helps students understand the English materials, improve language learning achievement, motivation, creativity, students' engagement, provide interesting activities, efficient learning, effective learning, lead autonomous learning, confident, and critical thinking. Student performance in the blended learning environment is as good as or better than traditional face-to-face learning (Li, Z., Tsai, M. H., Tao, J., \& Lorentz, C.,2014).

Based on the description above, researchers will conduct research related to online learning in Universitas Teknokrat Indonesia especially in English Education study program to obtain information about the impact of online learning on students' academic performance.

Online learning (E-Learning) is an ICT-based learning model. The carrying capacity of this program is ICT facilities in the form of a web LMS, monitoring program, modular and multimedia supplements. According to Satrio (2011), Elearning is learning that is structured with the aim of using an electronic system or computer so that it is able to support a learning process. Some benefits of Elearning are: (1) Flexible. E-learning provides flexibility in choosing the time and place to access trips, (2)Independent Learning. E-learning provides opportunities for learners to independently take control of learning success, (3) Cost Efficiency. E-learning provides cost efficiency for administrators, efficiency in the provision of physical facilities for learning and cost efficiency for learners is the cost of transportation and accommodation.

Among those benefits, there are some challenges in employing E-Learning in the classroom. E-Learning is also inseparable from various shortcomings, namely as follows: (1) Lack of interaction between lecturers and students, or even between students themselves, can slow down the formation of values in the teaching and learning process, (2) The tendency to ignore academic or social aspects and instead encourage business or commercial aspects, (3) The learning and teaching process tends toward training rather than education, (4) The change in the role of lecturers from previously mastering conventional learning techniques, is now required to master learning techniques using ICT (Information Communication Technology), (5) Students who do not have high learning motivation tend to fail, (6) Not all places have internet facilities (related to problems with the availability of electricity, telephones and computers).

The quality of education can be said to be qualified if the education implemented can produce the best graduates who have the ability of knowledge and skills that are useful for continuing to higher level of education and for 
entering the world of work. One of the successes of students in education is shown by their academic performance. But in fact, it is often found that the demands for academic performance on students are getting higher but their learning power is normal. This is what causes the student's success rate in academic performance to be less than optimal. Academic performance can be seen from the amount of GPA achieved and the length of time a person has studied at the University. Academic performance can be influenced by other factors such as achievement spirit competence, proactive competence, and professional competence. According to Anwar Prabu Mangkunegara (2000), performance comes from the word Job Performance or Actual Performance (actual work performance or achievement achieved by a person). The definition of performance is "the results in quality or quantity achieved by an employee in carrying out his duties in accordance with the responsibilities assigned to him. According to Alex Sobur (2006), the notion of academic achievement is a change in behavioral skills, or abilities that can increase over time and are not caused by a growth process, but a learning situation. It can be concluded that academic performance is the final result achieved by a person as success during education in an educational institution.

Several studies related to the effect of applying online learning models on student academic performance have been conducted.

1. Research conducted by Lulu Choirun Nisa entitled "The Effect of E-Learning Learning on Learning Outcomes in Statistics Course of English Tadris Students, Tarbiyah Faculty, Iain Walisongo" suggests that the average learning outcomes in Statistics of English Tadris students in semester II of 2010/2011 which was taught by the e-learning method was better than the average learning outcomes of students taught by conventional methods.

2. Research conducted by Euis Karwati entitled "The Effect of Electronic Learning (E-Learning) on the Quality of Student Learning" found that E-learning has a positive and significant effect on the quality of learning of FKIP UNINUS Bandung students. The influence is in the strong category. The more intensively e-learning is used, the learning quality of FKIP UNINUS students will also increase.

3. Research conducted by Sri Tomo and Bebas Widada entitled "The Effect of ELearning on Student Learning Achievement" found that the application of the ELearning website had a significant effect on learning motivation, individual performance, and student learning outcomes.

Based on previous research that has been described above, the researcher plans to identify the impact of online learning on student academic performance. This research is only applied on a small scale, limited to business correspondence course at Universitas Teknokrat Indonesia. In addition, researcher will also identify students' perceptions of online learning carried out during the Covid-19 pandemic. 


\section{METHOD}

The design used in this research is a qualitative descriptive method by developing the Creswell model (2012). The subjects of this study were students taking the Business Correspondence course from English Education study program, Universitas Teknokrat Indonesia. It consist of 40 students, where 14 of them were male, 26 of them were female. The consideration of choosing subjects and course is because the researcher is the lecturer of the course so that this can make it easier for researcher to carry out research. In addition, Universitas Teknokrat Indonesia was chosen as the research location with the consideration that the researcher is a permanent lecturer on the campus. Thus, researcher is expected to carry out research easily and efficiently. Furthermore, the facilities owned by the university are very adequate. The university has also required lecturers and students to carry out online learning using SPADA platform so that it is familiar to lecturers and students.

Instruments used in this research are questionnaire and open-ended interview. The questionnaire was used to describe the impact of online learning on student academic performance. The questionnaire will be developed using a Likert Scale which contains 22 statements which are developed into three parts, they are students' learning motivation, students' learning achievement, and students' involvement. The students' perception toward the statement can be strongly agree, agree, disagree and strongly disagree. All statements consist of positive statements. $50 \%$ of the total average score from agree and strongly agree indicates that online learning have positive impact on students' academic performance. The rest shows negative impact on students' academic performance. Open-ended interview was developed to gain data toward the students' perception on the use of online learning. The questions can be seen as follows:

1. Do you think that employing online learning during Pandemic is relevant?

2. Does Online learning have impact on your achievement compared to offline learning?

3. What are the strengths of online learning?

4. What are the challenges of online learning?

\section{RESULTS AND DISCUSSION}

\section{A. The Impact of Online Learning on Students' Academic Performance}

The result of the questionnaire reveals that online learning have positive impact on the students' academic performance. There are three categories that 
define students' academic performance; they are students' learning motivation, students' learning achievement, and students' engagement. The detail explanation can be seen below.

\section{Students' Learning Motivation}

Table 1. Impact of Online Learning on students' Motivation

\begin{tabular}{|c|c|c|c|c|c|}
\hline \multirow[b]{2}{*}{ No } & \multirow[b]{2}{*}{ Questionnaire Items } & \multicolumn{4}{|c|}{ Percentage (\%) } \\
\hline & & $\begin{array}{l}\text { Strongly } \\
\text { Agree }\end{array}$ & Agree & Disagree & $\begin{array}{l}\text { Strongly } \\
\text { Disagree }\end{array}$ \\
\hline \multicolumn{6}{|c|}{ Learning Motivation } \\
\hline 1 & $\begin{array}{l}\text { I enjoy learning Business } \\
\text { Correspondence through SPADA. }\end{array}$ & $12,5 \%$ & $70 \%$ & $17,5 \%$ & $0 \%$ \\
\hline 2 & $\begin{array}{l}\text { Materials of Business } \\
\text { Correpondence presented on slide } \\
\text { and video enables me to } \\
\text { understand the materials easily. }\end{array}$ & $22,5 \%$ & $70 \%$ & $7,5 \%$ & $0 \%$ \\
\hline 3 & $\begin{array}{l}\text { I can get more sources for learning } \\
\text { through internet that can support } \\
\text { the learning process. }\end{array}$ & $65 \%$ & $35 \%$ & $0 \%$ & $0 \%$ \\
\hline 4 & $\begin{array}{l}\text { I always take a part in discussion } \\
\text { forum. }\end{array}$ & $0 \%$ & $70 \%$ & $30 \%$ & $0 \%$ \\
\hline 5 & $\begin{array}{l}\text { I am challenged to learn English } \\
\text { through online learning. }\end{array}$ & $22,5 \%$ & $67,5 \%$ & $10 \%$ & $0 \%$ \\
\hline 6 & $\begin{array}{l}\text { I get new experience in learning } \\
\text { English by using new technique. }\end{array}$ & $0 \%$ & $80 \%$ & $20 \%$ & $0 \%$ \\
\hline 7 & $\begin{array}{l}\text { I want to pass the subject. So, I } \\
\text { study seriously for this course. }\end{array}$ & $62,5 \%$ & $37,5 \%$ & $0 \%$ & $0 \%$ \\
\hline \multirow[t]{2}{*}{8} & $\begin{array}{l}\text { I try to practice writing without } \\
\text { copy paste from internet. I want to } \\
\text { measure how far I understand the } \\
\text { materials. }\end{array}$ & $40 \%$ & $60 \%$ & $0 \%$ & $0 \%$ \\
\hline & Average & $28,12 \%$ & $61,25 \%$ & $10,62 \%$ & $0 \%$ \\
\hline
\end{tabular}

From the table above, it can be seen that most of the students do agree with the statements presented on the table. In other words, online learning have positive impact on students' learning motivation that later support the students' academic performance. It can be seen from the average score of the questionnaire. $61,25 \%$ of total respondents agree that online learning have impact on their learning motivation. $28,12 \%$ of the total respondents strongly agree with the statements given. It means that $86,37 \%$ of total respondents do believe that online learning have positive impact on their learning motivation. This result is also supported by previous research. The use of e-learning affects the motivation of learning. E-learning also has positive effect on student performance, motivation to 
learn, and positive effect on learning outcomes (Tomo, S \& Widada, B, 2014). In addition, applying E-learning boosts students' motivation. When the students are motivated, they tend to engage on e-learning process. Thus, they can achieve learning objectives (Kim \& W. Frick, 2011). The use of Moodle E-learning platform which consist of some interesting features can increases the motivation of the undergraduate students for the learning process (Abou El-Seoud, M., Taj-Eddin, I., Seddiek, N., El-Khouly, M., \& Nosseir, A. ,2014). Meanwhile, 10,62\% of the total respondents disagree that online learning have impact on students' learning motivation.

\section{Students' Learning Achievement}

Table 2. Impact of Online Learning on students' Learning Achievement

No Questionnaire Items

\section{Percentage (\%)}

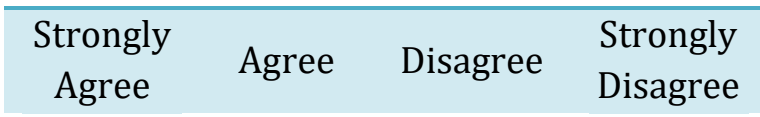

Students' Learning Achievement

\begin{tabular}{|c|c|c|c|c|c|}
\hline 9 & I get A or B for my final score. & $22,5 \%$ & $65 \%$ & $12,5 \%$ & 0 \\
\hline 10 & $\begin{array}{l}\text { I always submit assignment on post- } \\
\text { test. }\end{array}$ & $30 \%$ & $65 \%$ & $5 \%$ & 0 \\
\hline 11 & $\begin{array}{l}\text { I always complete quiz, mid test, and } \\
\text { final project. }\end{array}$ & $25 \%$ & $72,5 \%$ & $2,5 \%$ & 0 \\
\hline 12 & $\begin{array}{l}\text { I understand how to write text in } \\
\text { English correctly. }\end{array}$ & $47,5 \%$ & $45 \%$ & $7,5 \%$ & 0 \\
\hline 13 & $\begin{array}{l}\text { Given } 24 \text { hours access on the } \\
\text { material, I can get more time to read } \\
\text { and practice writing. }\end{array}$ & $22,5 \%$ & $70 \%$ & $7,5 \%$ & 0 \\
\hline 14 & $\begin{array}{l}\text { Online learning through SPADA } \\
\text { enables me to comprehend the } \\
\text { material on the slide easily. }\end{array}$ & $5 \%$ & $70 \%$ & $25 \%$ & 0 \\
\hline 15 & $\begin{array}{l}\text { Online learning through SPADA } \\
\text { provides Slide, video, discussion } \\
\text { forum, and post-test. }\end{array}$ & $45 \%$ & $55 \%$ & $0 \%$ & 0 \\
\hline & Average & $28,21 \%$ & $63,21 \%$ & $8,57 \%$ & 0 \\
\hline
\end{tabular}

From the table above, it can be seen that most of the students do agree with the statements presented on the table. In other words, online learning have positive impact on students' learning achievement that later support the students' academic performance. It can be seen from the average score of the questionnaire. $63,21 \%$ of total respondents agree that online learning have impact on their achievement. $28,21 \%$ of the total respondents strongly agree with the statements given. It means that $91,42 \%$ of total respondents do believe that online learning have positive impact on their learning achievement. Meanwhile, 8,57\% of the total 
respondents disagree that online learning have impact on students' learning achievement. On the other sides, the study conuducted by Belawati (2005) showed that student participation in online tutorials does indeed improve course completion rates and achievement. Online learning environment and supportive online behaviors are both important intermediaries between students' achievement goal orientations and their academic expectations (Yeh, Y. C., Kwok, O. M., Chien, H. Y., Sweany, N. W., Baek, E., \& McIntosh, W. A., 2019).

\section{Students' Engagement in Learning}

Table 3. Impact of Online Learning on students' Engagement

\begin{tabular}{|c|c|c|c|c|c|}
\hline \multirow[b]{2}{*}{ No } & \multirow[b]{2}{*}{ Questionnaire Items } & \multicolumn{4}{|c|}{ Percentage (\%) } \\
\hline & & $\begin{array}{l}\text { Strongly } \\
\text { Agree }\end{array}$ & Agree & Disagree & $\begin{array}{l}\text { Strongly } \\
\text { Disagree }\end{array}$ \\
\hline
\end{tabular}

Students' Engagement

\begin{tabular}{|c|c|c|c|c|c|}
\hline 16 & $\begin{array}{l}\text { I always discuss the materials to my } \\
\text { friends. }\end{array}$ & $50 \%$ & $50 \%$ & $0 \%$ & $0 \%$ \\
\hline 17 & $\begin{array}{l}\text { I always text my lecturer whenever } \\
\text { I get difficulty in understanding the } \\
\text { material. }\end{array}$ & $70 \%$ & $30 \%$ & $0 \%$ & $0 \%$ \\
\hline 18 & $\begin{array}{l}\text { I can access SPADA UTI from both } \\
\text { personal computer and mobile } \\
\text { phones. }\end{array}$ & $77,5 \%$ & $22,5 \%$ & $0 \%$ & $0 \%$ \\
\hline 19 & $\begin{array}{l}\text { Sometimes, I can not access SPADA } \\
\text { UTI for no reason. So, I texted my } \\
\text { lecturer asking for extended time } \\
\text { for assignment submission. }\end{array}$ & $40 \%$ & $60 \%$ & $0 \%$ & $0 \%$ \\
\hline 20 & $\begin{array}{l}\text { SPADA UTI can be access anytime } \\
\text { and anywhere. }\end{array}$ & $42,5 \%$ & $57,5 \%$ & $0 \%$ & $0 \%$ \\
\hline 21 & $\begin{array}{l}\text { Financial issue does not matter } \\
\text { during online learning. }\end{array}$ & $0 \%$ & $40 \%$ & $60 \%$ & $0 \%$ \\
\hline 22 & $\begin{array}{l}\text { Online learning enables me to learn } \\
\text { autonomously. }\end{array}$ & $37,5 \%$ & $40 \%$ & $22,5 \%$ & $0 \%$ \\
\hline & Average & $45,36 \%$ & $42,86 \%$ & $11,79 \%$ & $0,00 \%$ \\
\hline
\end{tabular}

From the table above, it can be seen that most of the students do agree with the statements presented on the table. In other words, online learning have positive impact on students' engagement that later support the students' academic performance. It can be seen from the average score of the questionnaire. 45,36 of total respondents strongly agree that online learning have impact on their learning engagement. $42,86 \%$ of the total respondents agree with the statements given. It means that $88,22 \%$ of total respondents do believe that online learning have positive impact on their learning engagement. Meanwhile, 11,79\% of the total respondents disagree that online learning have impact on students' learning 
engagement. Interestingly, $60 \%$ of total respondents disagree with the statement number 21. It indicates that most of them agree that financial issue does matter for online learning. According to Chen, P. S. D., Lambert, A. D., \& Guidry, K. R. (2010), there is a general positive relationship between the use the learning technology and student engagement and learning outcomes. In addition, the prediction of success in final exam emphasized the significant importance of engagement in various activities in the online course (Soffer, T., \& Cohen, A. 2019).

\section{B. Students' Perception Toward Employing Online Learning during Covid-19 Pandemic on Business Correspondence Course}

To gain the data of the students' perception, the researcher used open-ended interview. There were 5 questions being asked to the students. "S" indicates student. The result of the interview can be seen as follow:

\section{Relevancy of employing online learning during pandemic Covid-19}

The interview session gain more information whether it was a good decision on employing online learning during pandemic Covid-19. Based on the result of interview, most of the respondents agree that it was relevant to apply online learning.

S-1: "I think it is a good idea to switch offline to online learning during pandemic Covid-19 because it is safer. Another reason is that my lecturers have used SPADA to conduct online learning long before the pandemic"

S-2: "I have no problem with online learning because most of all subjects that I took employ blended learning by using SPADA. So, I don't get surprised"

S-3: "For the sake of being healthy, I think it is relevant to use online learning because online learning can be access anytime and anywhere. My lecturer gives me 24 hours to access the course"

From the result of interview above, it can be concluded that it is relevant to apply online learning during pandemic Covid-19. Most of the respondents have already used online learning through SPADA before the pandemic. Thus, it is notified that the students have been familiar with online learning. The COVID-19 pandemic has resulted in a sudden heavy reliance on the use of online learning. Enhancing teaching and learning during the pandemic requires careful attention to ensure that there is optimization of the range of currently available resources (Sandars, J., Correia, R., Dankbaar, M., de Jong, P., Goh, P. S., Hege, I., ... \& Webb, A., 2020).

\section{The Impact of Online Learning on Students' Achievement}

Based on the result of interview, it can be seen that online learning has positive impact on students' achievement. There is no different between conducting online and offline learning. The interview sample can be seen below. 
S-4: "There is no different in studying using online learning or offline learning in term of achievement. I can still participate the course because my lecturer provides material, video, discussion forum and assignment"

S-5: "I still get good score for Business Correspondence course because the learning process does not different a lot compared to offline learning. My weekly task is always assessed by my lecturer. Then, feedback is always be given to revise my writing. So, I know what's right and wrong on my writing"

S-6: "I have more time to read the materials and practice writing. So, it helps me to improve my writing skill so that I can understand how to produce good writing"

\section{The Strength of Online Learning}

One of points to ask during interview is related to students' perception toward the strength of online learning. Based on the result of the interview, it can be seen that the strengths of online learning include flexibility, accessibility, and boosting students' learning autonomously. course design, learner motivation, time management, and comfortableness with online technologies impact the success of an online learning experience (Song, L., Singleton, E. S., Hill, J. R., \& Koh, M. H., 2004). The sample of interview statement can be seen as follow.

S-7: "I think conducting online learning is flexible. I can conduct learning anytime and anywhere. I enjoy having online learning"

S-8: "I can access my course easily. Since internet is now easily to access, I can access my course from my mobile phone and personal computer."

S-9: "One of the strengths of online learning is I can learn by myself. But, when I get problem, I discuss to my friends and text my lecturer. My lecturer is easy to reach"

\section{The Challenges of Online Learning}

Based on the students' perception, there were some challenges in conducting online learning. The challenges include financial issue and bad internet access. It can be seen from the interview result.

S-10: "I need to spend more money to buy internet quota because the place where I live do not provide free internet access. Luckily, I do not live in my boarding house. So, the money that I should spend for living in my boarding house can be used to buy internet quota"

S-11: "I live in a village far away from the town. I get difficulty in access the internet because it does not always reach my place. I need to go to certain area near the internet provider tower to get full access of internet. It really bothers my learning process"

S-12: "I need to spend extra budget to buy internet quota. It really takes my money out" 


\section{CONCLUSION}

Based on the finding and discussion above, it can be concluded that online learning have positive impact on students' academic performance in terms of learning motivation, learning achievement, and learning engagement. Besides, students also showed that conducting online learning is relevant during pandemic. Furthermore, flexibility, accessibility, learning autonomy, and boosting students' achievement become the strengths of conducting online learning. However, financial issue and bad internet access become problems that hamper online learning.

\section{BIO-PROFILE}

Berlinda Mandasari is a lecturer at the English Education Study Program of Universitas Teknokrat Indonesia. She obtained her Master's degree from Universitas Sebelas Maret. Her research interests are Teaching Media, Teaching Assessment, Teaching Strategy, Teaching English as Foreign Language, and English for Business.

\section{REFERENCES}

Abou El-Seoud, M., Taj-Eddin, I., Seddiek, N., El-Khouly, M., \& Nosseir, A. (2014). Elearning and students' motivation: A research study on the effect of elearning on higher education. International journal of emerging technologies in learning (iJET), 9(4), 20-26.

Admin, "Mendikbud Terbitkan SE tentang Pelaksanaan Pendidikan dalam Masa Darurat Covid-19 24 Maret", Kemendikbud [Online]. Tersedia: https://www.kemdikbud.go.id [Diakses 3 Juni 2020].

Alex Sobur, (2006), Semiotika Komunikasi, Bandung: Remaja Rosdakarya Analisis Teks Media Suatu Pengantar untuk Analisa Wacana, Analisis Semiotik, dan Analisis framing, Bandung: PT Remaja Rosdakarya.

Anwar Prabu Mangkunegara, 2000, Manajemen Sumber Daya Manusia Perusahaan, Cetakan Ke-2, PT. Remaja Rosda Karya, Bandung.

Belawati, T. (2005). The impact of online tutorials on course completion rates and student achievement. Learning, Media and Technology, 30(1), 15-25.

Chen, P. S. D., Lambert, A. D., \& Guidry, K. R. (2010). Engaging online learners: The impact of Web-based learning technology on college student engagement. Computers \& Education, 54(4), 1222-1232.

Creswell, J. W. (2012). Educational research; planning, conducting, and evaluating quantitative and qualitative research. Upper Saddle River, NJ : Pearson Prentice- Hall.

Karwati, E. (2014). Pengaruh Pembelajaran Elektronik (E-Learning) terhadap Mutu Belajar Mahasiswa. Jurnal Penelitian Komunikasi. 17(1), 41-54. 
Khusniyah, N. L., \& Hakim, L. (2019). Efektivitas Pembelajaran Berbasis Daring: Sebuah Bukti pada Pembelajaran Bahasa Inggris. Jurnal Tatsqif, 17(1), 1933.

Kim Kyong-Jee and W. Frick Theodore, (2011), Changes in Student Motivation during Online Learning, Journal of Educational Computing Research, Vol44, Page(s) $1-23$.

Li, Z., Tsai, M. H., Tao, J., \& Lorentz, C. (2014). Switching to blended learning: The impact on students' academic performance. Journal of Nursing Education and Practice, 4(3), 245.

Mandasari, B., \& Aminatun, D. (2019). Uncovering Students' Attitude toward Vlogging Activities in Improving Students' Speaking Ability. Premise: Journal of English Education, 8(2), 214-225.

Nisa, Lulu Cahirun. (2012). Pengaruh Pembelajaran E-Learning terhadap Hasil Belajar Matakuliah Statistics Mahasiswa Tadris Bahasa Inggris Fakultas Tarbiyah IAIN Walisongo. Jurnal Phenomenon. 2(1), 7-27.

Sandars, J., Correia, R., Dankbaar, M., de Jong, P., Goh, P. S., Hege, I., ... \& Webb, A. (2020). Twelve tips for rapidly migrating to online learning during the COVID-19 pandemic. MedEdPublish, 9.

Satrio, A. (2011). Kendala Dan Penerapan E-Learning. Journal Information, 10, 116.

Soffer, T., \& Cohen, A. (2019). Students' engagement characteristics predict success and completion of online courses. Journal of Computer Assisted Learning, 35(3), 378-389.

Song, L., Singleton, E. S., Hill, J. R., \& Koh, M. H. (2004). Improving online learning: Student perceptions of useful and challenging characteristics. The internet and higher education, 7(1), 59-70.

Surat Keputusan Rektor Universitas Teknokrat Indonesia Nomor 002/UTI/B.18/III/2020t entang Pencegahan Penyebaran Corona Virus Desease (Covid-19) di Lingkungan Universitas Teknokrat Indonesia. 15 Maret 2020. Bandarlampung.

Tomo, S., \& Widada, B. (2014). Pengaruh Pemanfaatan E-Learning Terhadap Prestasi Belajar Mahasiswa (Studi Kasus STMIK Sinar Nusantara Surakarta). Jurnal Ilmiah SINUS, 12(1).

Wajdi, M. B. N., Kuswandi, I., Al Faruq, U., Zulhijra, Z., Khairudin, K., \& Khoiriyah, K. (2020). Education Policy Overcome Coronavirus, A Study of Indonesians. EDUTEC: Journal of Education And Technology, 3(2), 96-106.

Wajdi, M. B. N., Ubaidillah, M. B., Mulyani, S., Anwar, K., Istiqomah, L., Rahmawati, F., Hikmawati, S. A., Ningsih, D. R., \& Rizal, H. S. (2020). Pendampingan Redesign Pembelajaran Masa Pandemi Covid-19 bagi Tenaga Pendidik di Lembaga Pendidikan berbasis Pesantren di Jawa Timur. Engagement: Jurnal Pengabdian Kepada Masyarakat, 4(1), 266-277. 
Yeh, Y. C., Kwok, O. M., Chien, H. Y., Sweany, N. W., Baek, E., \& McIntosh, W. A. (2019). How College Students' Achievement Goal Orientations Predict Their Expected Online Learning Outcome: The Mediation Roles of Self-Regulated Learning Strategies and Supportive Online Learning Behaviors. Online Learning, 23(4), 23-41. 